\title{
BUILDING A TRUMP NATION: THE RHETORIC OF PRESIDENT DONALD J. TRUMP ON TWITTER
}

\begin{abstract}
This paper is an attempt to analyze the patterns of the $45^{\text {th }}$ President's use of Twitter for promoting his political agenda. Donald J. Trump used to "tweet" often even before entering politics; in the White House it is his primary instrument of contact with the U.S. society, bypassing the established media channels. A special emphasis was put on the rhetorical characteristics of Trump's social media communications as well as the identity-building aspect of his Twitter oratory. The research was conducted with the use of the method of quantitative content analysis. Obtained results point out to the Republican as an unconventional political player, employing the possibilities offered by new media in an original yet effective manner.
\end{abstract}

Keywords: Donald Trump, rhetoric, president, United States of America, social media

\section{Introduction}

Recent political events prove the significance of new media for democratic processes all around the world. The year 2016, especially, brought about a wave of unexpected results of elections and referenda in numerous countries, giving fuel to discussions about the evolution of voters' behavior in contemporary societies. For example, the circumstance that the public discourse in the last couple of years has moved to a large extent to the Internet is often put forward as one of the deciding factors in the surprising political shift that resulted in the election of Donald J. Trump as the U.S. President. For better or for worse, online communication changed the way in which gathering political support is done today and the consequences of this transformation can be observed in many modern political operators' campaigning playbooks.

It should be emphasized that communication in the new media is a dynamically evolving weapon in the electoral arsenals of campaign staffs. Tricks that used to 
work well just a few years earlier might not be successful in the next election; skillful employment of the opportunities that are presented to political organizations by the World Wide Web is still an art in statu nascendi. One of the leading Internet's campaigning gurus, Colin Delany, admitted already in 2011 in his political communication manual: "this version of Online Politics 101 (the fourth edition) was obsolete about five minutes after I finished the last draft, since someone in a basement or garage is already creating tools that'll change the ways we do online politics forever" (Delany, 2011, p. 64).

Since we know from the writings of Harold Innis and Marshall McLuhan that the very form of a medium used is one of the principal factors that shape communication processes (McLuhan, 2013, pp. 7-22), it is worth exploring how the characteristics of the new media impact contemporary political discourse. Just like Franklin Delano Roosevelt, the early champion of radio "Fireside Chats", and Richard Nixon, who unleashed the power of television on the unsuspecting American voters, the incumbent (as of 2020) U.S. President, Donald J. Trump seems to stand on the forefront of a new paradigm shift of political communication. Whereas his predecessors have employed online channels to reach out to the United States society as well (Barack Obama's 2008 campaign was especially praised for its innovative social media instruments), Trump's ingenious, intensive use of the microblogging service Twitter as the primary means of communication deserves special scrutiny. Particularly interesting here is how the traditional tenets of presidential rhetoric and the idiosyncratic qualities of Trump's oratorical style are adapted to this new communication platform.

This paper is an attempt to analyze the patterns of the $45^{\text {th }}$ President's use of Twitter for promoting his political agenda. Donald J. Trump used to "tweet" often even before entering politics; in the White House it is his primary instrument of contact with the U.S. society, bypassing the established media channels and ostensibly reverting American political communication to its direct (Dobek-Ostrowska

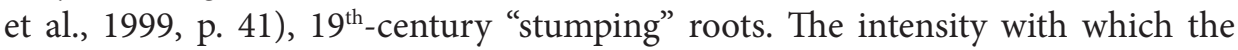
Republican uses the popular microblogging service - the high frequency of his tweets, their extremely personal, "unpolished" character, and repeatedly controversial content - makes it a compelling subject of research. A special emphasis was put on the rhetorical characteristics of Trump's social media communications as well as the identity-building aspect of his Twitter oratory.

\section{Twitter as a Social Networking Service}

Twitter, established in 2006, may be best described as a microblogging service with social networking functionalities. The distinguishing feature of the service was the restriction of a single message's length to merely 140 characters, corresponding with the original size limit for 8-bit characters in the SMS (Short Message Service) 
mobile communication protocol (in November 2017 this limit has been increased twofold, to 280 characters). Those postings, referred to as "tweets", might include hyperlinks to external content, multimedia, or the so-called "hashtags", allowing for easy categorizing, aggregating, and searching messages (Sánchez, 2018, p. 239). The model of "blogging" that is utilized by Twitter users is quite distant from the original meaning of the verb. First used in 1997 by John Barger, the term "blog" (from "web log") was supposed to stand for a kind of personal register of visited websites, with brief descriptions thereof, published as a "road map" for other Internet users (Olszański, 2006). Subsequent years brought about an evolution of blogging, including the best known form of an intimate yet public personal diary, as well as further reformulations of this idea - towards political commentary platforms, image journals, and video blogs (or "vlogs"), among many others. Blogging functionalities are also a staple feature of social networking sites (SNSs), offering users an opportunity to share content with others and thus keeping them interested in returning to the service (early SNSs, such as the pioneering Six Degrees, did not have this functionality and tended to lose users over time).

Danah $\mathrm{m}$. boyd i Nicole B. Ellison define social networking sites as "web-based services that allow individuals to 1) construct a public or semi-public profile within a bounded system, 2) articulate a list of other users with whom they share a connection, and 3) view and traverse their list of connections and those made by others within the system" (boyd, Ellison, 2007, p. 211). Twitter does fulfill these criteria, yet in contrast to the most popular model (adopted, inter alia, by Facebook), its system of personal connections - between the "followers" and the "followed" - does not require a confirmation of a mutual relationship. The unidirectional character of the service's network of acquaintances makes communication on Twitter more resemblant to the classic, "one-to-many" model of mass media.

As John H. Parmelee noticed already in 2013, merely seven years after the service's establishment, "in the U.S., Twitter is used by the president, a majority of members in Congress, most governors and mayors, as well as candidates and political operatives" (Parmelee, 2013, p. 4). Reasons for using Twitter by politicians include self-promotion and spreading information about issues regarded by them to be important (Golbeck et al., 2009). Polish scholar Marek Jeziński offers - in the context of political blogging - an original classification of the functions of this form of communication: a) political self-creative function (building an attractive image), b) expressive-emotive function (calling for action), c) aesthetic function (creating an image of a stylistically competent person), d) integrative-exclusive function (building a community around shared ideas and values, while simultaneously stigmatizing opponents), e) impressive-agitational function (promoting one's opinions), f) informative function (bringing a matter up for discussion), g) phatic function (establishing and maintaining rapport) (Jeziński, 2009, pp. 181-190). While it could be argued that all of these functions can be identified to some extent in the 
$45^{\text {th }}$ U.S. President's communications on Twitter, in this paper we will focus primarily on the community-building function.

In his Twitter activities, President Trump uses two accounts (whose authenticity has been confirmed by the service's administrators): the official presidential account, inherited from Barack Obama (@POTUS), and his own private account (@realDonaldTrump), used previously by the Republican in his numerous business and media endeavors. The first, historic message, sent from Trump's account in May 2009, promoted his appearance at Late Show with David Letterman on the CBS television network. BBC's Adam Harris reports that the first years of the future U.S. President's microblogging career went relatively smoothly: "there were tweets about The Apprentice, his appearances, family milestones and quotes from Mr Trump himself. The tweets (...) rarely veered into politics" (Harris, 2016). Only 275 messages were tweeted from Trump's account until May 2011, and they specified clearly whether the postings had been written by the businessman himself or by his public relations team.

Production of new content on @realDonaldTrump accelerated dramatically in subsequent years, reaching the average output of 375 tweets per month during the 2016 presidential campaign. Trump himself pointed out that the hectic pace of his Twitter activities stemmed from lack of trust in the established media outlets (which he routinely accuses of supporting his political opponents), tweeting in 2016: "If the press would cover me accurately \& honourably, I would have far less reason to 'Tweet"' (Harris, 2016). The personal, candid, and spontaneous character of his Twitter communications, ostensibly not censored by the Republican's press team, caused Trump a plenty of minor image problems and made him susceptible to trolling. In September 2014, the future President retweeted (i.e. shared on his account) a message of a Twitter user who posted a photo of the notorious British serial killers Fred and Rose West with a note claiming that Donald J. Trump was a "big inspiration" for them (Selby, 2014). Much larger media outrages were caused by Trump's thoughtless retweeting of messages originally posted on fascist or racist Twitter accounts (such as @ilduce or @WhiteGenocideTM). Commentators often criticize minor linguistic mistakes or clumsy grammar in Donald J. Trump's tweets, such as the famous neologism "covfefe", originally coming from a message published in May 2017 (the 45 $5^{\text {th }}$ U.S. President presumably attempted to write "coverage" but for some reason did not succeed at this task).

The official presidential account (@POTUS) is currently, as of February 2020, followed by 28.4 million users, while Trump's private account (@realDonaldTrump, on which this paper is primarily focused) has more than 73 million followers. 


\section{Donald J. Trump as a Political Operator}

It might be argued that the political career of Donald J. Trump will go down as the most astonishing development in the recent history of the United States. Trump, an heir to a real estate business empire and one of America's most controversial celebrities, was an unlikely candidate for challenging established politicians from both major parties. With his flamboyant lifestyle (Kirsten Theye and Steven Melling note that "during his 40-plus years as a celebrity, the Trump spectacle has never failed to deliver headlines and media mentions"; 2018, p. 331), numerous marriages, and an eclectic set of regularly reversed political positions, he matched even less the stereotypical profile of a Grand Old Party statesman. Nonetheless, Trump was able to beat the odds in the 2016 presidential campaign, surprising both seasoned political analysts (including, notoriously, Nate Silver of fivethirtyeight.com ${ }^{1}$ ) and himself (Wolff, 2018, p. 27). His political platform may be best described as populist, based primarily on distrust towards the Washington establishment, conservative on both economic and social issues, and placing a special emphasis on immigration (with the construction of a wall on the U.S.-Mexican border as the signature policy). Donald Trump's presidency run was among the most lively and dramatic events in American politics in the last decades, with the media reporting every detail of the Republican's activities, and the red baseball cap with the slogan "MAKE AMERICA GREAT AGAIN" on front a visible symbol of the rising movement (Gounari, 2018, p. 221).

The themes of Trump's campaign mirrored to some extent the modern Republican strategy of focusing on potentially controversial, reverberating social and cultural issues, such as abortion or the place of religion in public life (albeit not as consistently as in the case of some of his conservative rivals). Historian Thomas Frank argues that this tactic has been crucial in selling the Grand Old Party's free market economic programs and initiatives to working class and rural voters who have no personal interest in supporting such policies, skillfully diverting their attention to "cultural battles where victory is impossible" (Frank, 2004, p. 121) and rallying against the "liberal elites", allegedly hostile to the traditional American values. ${ }^{2}$ This emphasis on emotionally-charged points of moral contention provides high octane fuel for Trump's oratory, allowing his strategists to carefully build a siege mentality among supporters and the President himself to showcase his unorthodox rhetorical skills.

1 Nate Silver is an American data journalist and writer who achieved publicity in 2008 for his correct and extremely precise predictions of that year's presidential race (Silver, 2015), repeated this feat in 2012, and then failed in his 2016 prognosis.

2 Robert Schertzer and Eric Taylor Woods argue that Trump "tended to frame his opponents and the establishment as enemies of the people" (understood as a predominantly White "silent majority" of the American nation) during his presidential campaign (Schertzer and Woods, 2020, p. 10). 
Donald J. Trump's public communication initiatives distinguish him from the vast majority of American political figures. In vivid contrast to his direct predecessors: Barack H. Obama, usually regarded as a textbook orator with an added advantage of extraordinary stage abilities (Kuś, 2016, p. 101), and George W. Bush, whose folksy charm (Greene, 2006, p. 152) and conversational skills allowed him to effectively reach out to common people while maintaining the appropriate decorum in situations that required it, Trump's rhetoric is obviously less inspired by standard public speaking manuals. One of its most significant traits, it might be argued, is the relative lack of adjustment of a given speech for a specific venue and audience (which obviously is one of the basic tenets of conventional rhetorical wisdom). Excluding a few exceptional cases, such as some of the State of the Union addresses (or the 2017 Warsaw oration), Trump's speeches generally sound alike, all of them bearing his unmistakable, idiosyncratic flavor. Full of colorful lexical choices, frequent repetitions ("staccato bursts of repeated phrases"; Theye and Melling, 2018, p. 326), and radical yet not always factually correct, heat-of-the-moment statements, they lack the high level of polish (typical, for example, for Obama's rhetorical initiatives), often devolving into comparatively shapeless rants or litanies of political slogans.

Still, while it is perhaps quite safe to say that future scholars of presidential rhetoric will not hold Trump's speeches in the same regard as in the case of Lincoln, Kennedy, or Reagan's orations, one cannot deny their efficiency as instruments of political communication (which is really all that matters, as rhetoric is regarded to be a pragmatic art of finding the available means of persuasion for each particular subject; Bendrat, 2016, p. 180). For one, Trump's recurrent use of slogans and catchphrases ("make America great again", "crooked Hillary", "drain the swamp") makes his oratory a prime source of "sound bites" (short excerpts of a larger clip, routinely used in broadcast media to represent the full length statement; Postman and Powers, 2008, pp. 84-85). By providing news teams with what effectively is a pre-made "sound bite", a politician might (to some extent) control his portrayals in radio and television, ${ }^{3}$ rendering his overall message more coherent. The apparently careless and chaotic composition of Donald J. Trump's speeches gives them also an "authentic" feel, reinforcing his image as an honest person "speaking as it is" and organically unable to embellish the facts or use diplomatic doublespeak (Theye and Melling, 2018, pp. 329-332). To many ears, an impeccably tailored public oration sounds (and perhaps rightly so!) artificial, like a pop music song that was written by a team of veteran lyricists, focus-group tested, professionally produced, and auto-tuned to perfection, but is still lacking heart and emotional sincerity.

This observation brings us to the $45^{\text {th }}$ President's greatest forte as a public speaker: the ability to effectively use rhetorical ethos as an instrument for strengthening the impact of his orations. Aristotle distinguishes three main components of ethos,

3 As well as set the agenda for media stories (Gallagher, 2019, p. 184). 
or proof from credibility of the speaker: competence and wisdom (phronesis), moral virtue (arete), and goodwill towards the audience (eunoia). In case of Donald J. Trump, the aspect of phronesis is achieved via his personal narrative of a successful businessman of immense wealth, an experienced dealmaker who literally wrote a book about negotiations (McAdams, 2017, p. 2), and a tough, outspoken person who is not afraid of confronting powerful opponents and making important decisions (an image he has cultivated in his numerous media appearances ${ }^{4}$ ). Arete, perhaps the most risky part of ethos for a bon vivant like Trump (especially taking into consideration his predominantly religious electorate), ${ }^{5}$ is constructed in opposition to his political enemies, the allegedly immoral "liberal elites". Charging against the twin-headed dragon of "secularism" and "socialism", Donald J. Trump becomes St. George by default. The third of the pillars, eunoia, is attained primarily through close rapport between Trump and his audience; the $45^{\text {th }}$ President genuinely thrives in the presence of a sympathetic crowd, projecting an aura of mutual understanding and confidence. It can be argued that the effusive use of slogans in his oratory is a smart rally strategy as it enables audience to participate in the performance itself (for example by chanting catchphrases), strengthening the feeling of togetherness. Additional factors include such distance-reducing measures as the casual register of language used (rendering Trump "one of us") and the alleged communion of values threatened (in a sort of a besieged city scenario) by common adversaries. This allows for construction of a loyal supporter base, cultivated by means of diverse communication channels operated by Donald J. Trump and his public relations staff - and including Twitter.

\section{Making America Great Again (One Tweet at a Time)}

The following study comprises an analysis of Donald J. Trump's messages, published on his Twitter account (@realDonaldTrump) during a period of one week: between September $24^{\text {th }}$ and September $30^{\text {th }}, 2019$. The choice of the time and duration of the analysis was determined by factors including: the currentness of messages (so as to capture Trump's microblogging idiosyncrasies in their present form, as

4 Including NBC's popular reality show "The Apprentice", hosted by Trump (Castleman and Podrazik, 2016, p. 429), in which he frequently used the catchphrase "You're fired!", cementing his image of a ruthless but competent manager.

Some anecdotal evidence for this can be found in an interview the author of this paper conducted (as a part of an unrelated research project) during a teaching mobility in New York in the spring of 2019. A Polish American local activist, Catholic leader, and staunch Trump supporter stated: "As a person, Donald Trump is abhorrent to me. But the things he does as President are good".

6 The plain style (subtile) is one of the three main styles used in classical rhetoric (Korolko, 1998, p. 53; see also: Kajtoch, 2007, p. 413). Brian L. Ott argues that "when Trump's public discourse is run through the Flesch-Kincaid grade-level test, it rates at a $3^{\text {rd }}$ or $4^{\text {th }}$ grade reading level" (Ott, 2017, p. 63). 
of late 2019), presence of significant political events relevant to Trump's presidency (the week in question commenced with the announcement of the impeachment inquiry by the U.S. House of Representatives Speaker Nancy Pelosi on September $24^{\text {th }}$ ), as well as practical time limitations for a content analysis procedure (taking into consideration the high intensity of Twitter use by the Republican, as well as variables concerning the diversification of individual tweets and dispersion of their examined traits and elements, the amount of messages collected was deemed sufficient to conduct a meaningful research; Lisowska-Magdziarz, 2004, pp. 61-66; Wimmer and Dominick, 2008, pp. 218-221).

The query brought about 248 tweets; this quantity represents a busy spell online for the $45^{\text {th }}$ President (with the average of a little more than 86 messages per seven days in the period from Trump's inauguration in January 2017 to November 2019, which is more or less equal to his tweeting pace from the 2016 presidential campaign). Almost all these posts were sent using an iPhone Twitter application, which constitutes a change from the early days of his presidency when more than half of his tweets came from Trump's Android device. This circumstance prompted media discussions and some ingenious research into how the microblogging service was used by the President and his staff. Analyst David Robinson points out to several subtle but significant differences between @realDonaldTrump tweets sent from Android and iPhone devices at that time, including: the hour when the message was published, presence of pictures, links, and hashtags, as well as lexical choices and the overall tone of the tweet. "When Trump wishes the Olympic team good luck, he's tweeting from his iPhone. When he's insulting a rival, he's usually tweeting from an Android", concludes Robinson (2016), implying that only the Android posts were written by the President himself, with the rest being the creation of his media team. Trump stopped using his Android phone in March 2017, preventing (or at least making more difficult) this kind of insight behind the scenes.

The analyzed tweets were carefully collected and processed, using the online tools available at TrumpTwitterArchive.com website, ${ }^{7}$ double-checked with the original content, cleaned, and then archived in a Microsoft Excel spreadsheet. Subsequently, units of content analysis (i.e. individual messages) were coded with a system of categories designed to scrutinize relevant aspects of the posts.

Among the tweets published by Trump in the analyzed period no less than 203 (or almost 83\%) were focused directly on the impending impeachment inquiry, revealing deep concerns of the Republican administration about the proceedings. More than $10 \%$ of the postings dealt with further issues of federal politics (occasionally concerning impeachment as a part of the message), with the rest covering such diverse topics as business, international relations, media, and the military and including some seasonal greetings as well (fig. 1).

7 Among the advantages of using a specialist service such as TrumpTwitterArchive.com is the ability to easily convert the selection of tweets to a preferred format and to access messages that had been deleted from the original feed (access: 1.01.2020). 
Figure 1. Issues discussed in Donald J. Trump's Twitter messages in the analyzed period

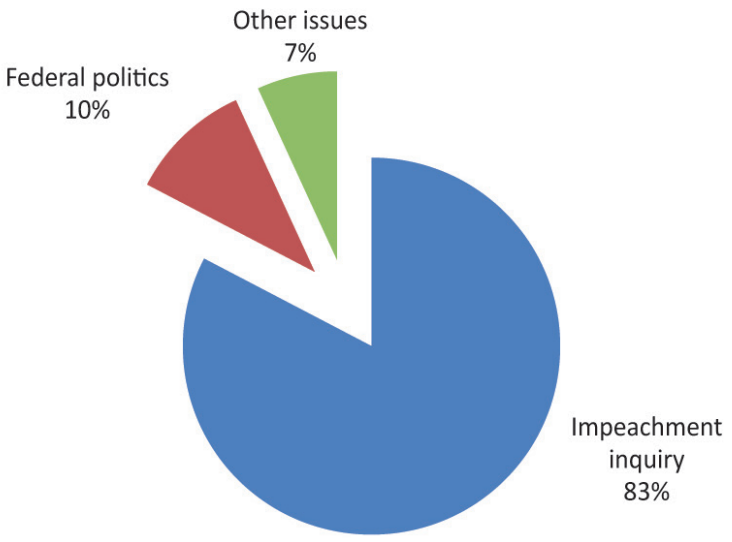

Source: own research.

The operators of the $45^{\text {th }}$ President's personal Twitter account used several tactics in order to fight off allegations of an impeachable abuse of power in the U.S.Ukrainian diplomatic relations in 2019, the first of which was to give the floor to Trump himself. In his microblog postings, the Republican often utilized the same kind of vivid, evocative language he is known for in his real-life public speaking endeavors. The peculiarities of Trump's Twitter rhetorical style include the practice (very often found in Internet communication but perhaps not that subtle) of frequently using capital letters for emphasis. Examples include such phrases as: “(...) he completely changed the words to make it sound horrible, and me sound guilty. HE WAS DESPERATE AND HE GOT CAUGHT. Adam Schiff therefore lied to Congress and attempted to defraud the American Public (...)", "THE GREATEST SCAM IN THE HISTORY OF AMERICAN POLITICS!", or “THE DEMOCRATS ARE TRYING TO DESTROY THE REPUBLICAN PARTY AND ALL THAT IT STANDS FOR. STICK TOGETHER, PLAY THEIR GAME, AND FIGHT HARD REPUBLICANS. OUR COUNTRY IS AT STAKE!" (Trump Twitter Archive, 2019). Even when not in the full caps mode, Donald J. Trump has the predilection to capitalize the initial letters of selected words of his messages: "(...) the great success we are having with the Economy, the Military, Vets, Tax and Regulation Cuts, HealthCare, and so much more!", "How do you impeach a President who has created the greatest Economy in the history of our Country, entirely rebuilt our Military into the most powerful it has ever been, Cut Record Taxes \& Regulations, fixed the VA \& gotten Choice for our Vets (after 45 years), \& so much more?..., or “(...) it is also disgraceful what they are NOT doing, namely, the USMCA vote, Prescription Drug Price Reduction, Gun Safety, Infrastructure, and much more!" (Trump 
Twitter Archive, 2019), rendering them resemblant to the early modern era orthographic tenets of English, while in deed making the key issues more noticeable in his postings.

One of the major weapons in Trump's oratorical arsenal, as it has already been stated, is the use of slogans and catchphrases to convey his message. Twitter, due to its trademark limitation of a posting's length, which forces users to be brief in their statements, is arguably a medium that perfectly fits this strategy. In fact, no less than five tweets posted (or reposted) in the analyzed period consisted only of the slogan "I AM DRAINING THE SWAMP" (all capital letters), with the phrase appearing once again in the end of a longer posting. Long-time supporters' favorites such as "MAKE AMERICA GREAT AGAIN" and "KEEP AMERICA GREAT" also make appearances in the analyzed corpus, with a new catchphrase "PRESIDENTIAL HARASSMENT!" (for the impeachment inquiry) tweeted twice during the week in question. The inquiry has also been described as "Impeachment Scam" or "Witch Hunt" (14 times in the corpus), ${ }^{9}$ as in the obviously hyperbolic "the Greatest and most Destructive Witch Hunt of all time!" or "a total Witch Hunt Scam by the Democrats", combining the two expressions (Trump Twitter Archive, 2019).

Another persuasive tactic used by Donald J. Trump involves the frequent use of elaborate etiquettes in order to criticize or denigrate his opponents (Galan and Piórecka, 2018, p. 61). Devised with ingenious creativity by the Republican (or his campaign), they are meant to evoke certain associations in the audience if used sufficiently often, constructing a durable mental connection between a given object and a negative epithet ("crooked Hillary", "fake media"). During the analyzed period, the most glaring example of such a strategy was the descriptor "do nothing", utilized in combination with the Democrats seven times in the corpus, e.g. "Do Nothing Democrat Savages", "The Democrats are now to be known as the DO NOTHING PARTY!", and “These Radical Left, Do Nothing Democrats, are doing great harm to our Country". Derogatory labels are attributed in Trump's feed to individual political operatives as well, with the examples including "Sleepy Joe" [Biden - R.K.], "\#FakeWhistleblower" (used as a hashtag), and "Liddle' [sic! - R.K.] Adam Schiff" (used four times in the corpus). The unusual spelling of the word "little" used to describe Representative Schiff led to some media confusion and a bizarre clarification tweeted by the $45^{\text {th }}$ President of the United States in a subsequent message: "To show you how dishonest the LameStream Media is, I used the word Liddle, not Liddle, in discribing [sic! - R.K.] Corrupt Congressman Liddle' Adam Schiff. Low ratings @CNN purposely took the hyphen ${ }^{10}$ [sic! - R.K.] out and said I spelled the word little wrong. A small but never ending [sic! - R.K.] situation

8 This expression was first used by Trump on Twitter already in November 2018.

9 As well as "impeachment charade" (in a retweeted post).

10 In the aftermath of Trump's tweet, even the team behind Merriam-Webster dictionary's Twitter account felt obliged to weigh in and explain the difference between a hyphen and an apostrophe in a reply post. 
with CNN!" (Corbett, 2019). The additional mistakes made in the posting may be seen as both ironic and endearing, perfectly fitting the unpolished, candid nature of the Republican's tweets. Donald J. Trump's criticism of political opponents may be also conveyed by labeling them members of a condemnable group: "AOC Plus 3" (a moniker for Alexandria Ocasio-Cortez and three other Democratic congresswomen of color: Ilhan Omar, Ayanna Pressley, and Rashida Tlaib, first used by conservative journalist Laura Ingraham and quickly adopted by Trump) and "Pelosi \& the Squad" (in a retweeted message; Trump Twitter Archive, 2019).

Trump's deep distrust and enmity towards the majority of established media outlets (as seen in the quoted message; see also Maguś, 2018, p. 15) leads to the coining of similar phrasal expressions, including (in the corpus): "fake news" (6 times), "Fake News Media" (4 times, including a hashtag version \#FakeNews Media), "LameStream Media", and "corrupt news media". Especially intriguing but perfectly understandable, taking into consideration the Republican's business background and the commercial nature of the American media system, is the use of descriptions denoting market failure as derogatory epithets: "Failing New York Times", utilized in an elaborate tweet questioning the integrity of a journalist - "Obama loving (wrote Obama book) Peter Baker of the Failing New York Times, married to an even bigger Trump Hater than himself, should not even be allowed to write about me. Every story is a made up disaster with sources and leakers that don't even exist" and the already cited "Low ratings @CNN" (Trump Twitter Archive, 2019).

Fortunately for Trump, not every broadcaster is his enemy; the corpus is full of praise for those press outlets that the $45^{\text {th }}$ President regards as faithfully serving the American nation. Trump's media recommendations include Sean Hannity's Fox News show: "Will be a GREAT and very accurate show tonight by @seanhannity on @foxnews (9:00 PM)" and a new book by author Andrew C. McCarthy: "Great new book by the brilliant Andrew McCarthy, BALL OF COLLUSION, THE PLOT TO RIG AN ELECTION AND DESTROY A PRESIDENCY. Get it, and some other great new books which I will soon be recommending. They tell you about the Crooked Pols [sic! - R.K.] and the Witch Hunt that has now been exposed!" (Trump Twitter Archive, 2019). Incidentally, worth noticing here is the widening rift between the allegedly liberal and conservative media outlets, shaping the American public discourse and clearly visible in the above excerpts from Donald J. Trump's oratory. This situation (of the so-called external pluralism of the media system) is a recent development in the United States, especially in broadcast media, and has traditionally been more associated with certain European countries (Hallin and Mancini, 2004, p. 29). 
Even the most charismatic public speakers need occasionally to draw their rhetorical credibility from external sources. ${ }^{11}$ Due to the very nature of communication on Twitter, allowing for easy reposting of other users' messages, the microblogging service seems to be an excellent platform for collecting and displaying expressions of support, thus creating a persuasive social proof (Cialdini, 2000, pp. 98-111). The $45^{\text {th }}$ President frequently uses the opportunity to do so, with roughly half of his Twitter communications (almost 49\%) being retweets. The roster of users whose messages have been shared by Trump during the analyzed period is eclectic and includes - inter alia - political operatives, sympathetic journalists, members of his immediate family, as well as ordinary people coming from all walks of life (at least seemingly ${ }^{12}$ ). The first category comprises the Republican National Committee itself (\#GOP) and its research department RNCResearch (\#RNCResearch), providing Donald J. Trump's feed with news and conservative political commentary. In the days following Nancy Pelosi's announcement, the President's account retweeted as well numerous statements from the Grand Old Party senators and representatives expressing solidarity and support for Trump. The second group includes notable figures of American conservative media outlets, whose supporting opinions have been occasionally presented through an attached video file (many of them are associated with Fox News television channel or the controversial far-right news and opinion website Breitbart). The third category comprises the $45^{\text {th }}$ President's children: Donald Trump Jr. (8 retweets), Eric Trump (2 retweets), and Ivanka Trump (1 retweet). Ivanka's supporting message was reposted by the President with the comment "So cute! Her father is under siege, for no reason, since his first day in office!", cultivating his image as a loving family man (Trump Twitter Archive, 2019).

Perhaps the most interesting category of presidential retweets comprises Twitter accounts of ordinary Americans and amateur Internet publications. In the analyzed period, they included such Twitter users as @JNedster ("Concerned American | Conservative | Football Fan | Star Trek Geek | Have Been Retweeted By President Trump”), @RafBo (“\#DEPLORABLE \#PATRIOT \#MAGA \#KAG \#1A \#2A \#Veteran \#Christian \#ConstitutConserv \#Physician \#MartialArtist \#AmateurCoinMagic \#AmateurAstronomy \#JeepOffRoad4W \#DIY”), and @notable_ink (“Sharing notable historical American quotes and art. RT'd by POTUS!! SWCCFP They got to me so.. I'm starting over with a new account"). Worth noticing here is the pride, prominently displayed by @JNedster and @notable_ink in their profile

11 A good example here would be President John F. Kennedy in the famous "Ich bin ein Berliner" speech. Despite coming to West Berlin as the leader of the free world and thus getting most of his ethos by default, he spent the first part of his oration drawing rhetorical credibility from the men surrounding him on the tribune, including General Lucius D. Clay and Chancellor Konrad Adenauer.

12 There is no telling whether a non-verified Twitter account is in fact operated by a given person. One of the most popular strategies of dishonest online political marketing is to use fake social media accounts in order to influence the public. Worth noticing here is the fact that two Twitter accounts whose postings Trump retweeted in the analyzed period have been later suspended by the service. 
information, of having their postings shared by the President himself. Whether or not these accounts are authentic (and there is no reason to assume that none of them are), this apparent practice of giving the floor to common people and appreciating their thoughts must be commended from the community-building point of view and certainly is a prime example of the integrative function of political blogging, as in the previously mentioned Jeziński's classification.

While Donald J. Trump's Twitter account was used in the analyzed period primarily for attacking the President's political enemies or defending against them, its operators found some time for more positive content as well. Economic successes of the Republican administration were particularly celebrated, with five enthusiastic tweets, such as "Navistar will be building a new 250 MILLION DOLLAR truck factory in San Antonio with 600 new jobs. Congratulations San Antonio and Texas! America makes the GREATEST trucks in the world!" and the feel-good, charmingly self-aggrandizing ${ }^{13}$ "China is doing very poorly while the USA, under your favorite President's leadership, continues to soar to new heights - and, despite the Do Nothing Democrats, we have just begun!" (Trump Twitter Archive, 2019). On six occasions (in the corpus), the $45^{\text {th }}$ President expressed his support for political allies and nominees, including Senator Shelley Moore Capito, Representative Doug Collins, and General Mark Milley. He sent seasonal wishes once (in what can be seen as another community-building initiative), for the Rosh Hashanah holiday.

\section{Conclusion}

While Donald J. Trump's presidency remains one of the most divisive developments in the recent political history of the United States and his unconventional statements and initiatives keep on spawning new controversies every day, one cannot deny that the Republican must have been doing something right in order to be able to reach the very top of the American federal government and stay there, with an unwavering support of roughly half of the nation. This paper attempts to shed some light on Trump's success by pointing out to the peculiarities of his style of political communication, allowing him to ingeniously maneuver the new media in order to gain political advantage and build a loyal following. Twitter, the Republican's microblogging platform of choice, was proven in the above analysis to be an especially useful instrument for such strategies. It might be argued that any presidential hopeful in the present era should take notice of the uncompromising, in-your-face style of the $45^{\text {th }}$ President's online presence. For worse or for better, it has indeed transformed the way politics is done in America.

13 Merritt Moseley correctly observes that Trump's braggadocio is actually well rooted in the American culture: "Donald Trump has raised celebrating himself to a level previously unknown in the American presidency. But this is also in the American grain” (Moseley, 2018, p. 61). 


\section{Bibliography}

Bendrat A. (2016). Mowa jest złotem. Amerykański prezydent i retoryka. Warszawa: Instytut Badań Literackich PAN.

boyd d.m., Ellison N.B. (2007). "Social Network Sites: Definition, History, and Scholarship”. Journal of Computer-Mediated Communication, 13, pp. 210-230. DOI: https://doi. org/10.1111/j.1083-6101.2007.00393.x.

Castleman H., Podrazik W.J. (2016). Watching TV: Eight Decades of American Television. Syracuse: Syracuse University Press.

Cialdini R.B. (2000). Influence: Science and Practice. $4^{\text {th }}$ ed. Boston: Allyn \& Bacon.

Corbett E. (2019). Trump Has Called His Political Foes "Liddle" Before: Here's What He Means. Retrieved from: https://fortune.com/2019/09/27/what-does-liddle-mean-trump-chyronschiff/ (access: 1.01.2020).

Delany C. (2011). Online Politics 101: The Tools and Tactics of Digital Political Advocacy. Retrieved from: https://www.epolitics.com/onlinepolitics101.pdf (access: 1.01.2020).

Dobek-Ostrowska B., Fras J., Ociepka B. (1999). Teoria i praktyka propagandy. Wrocław: Wydawnictwo Uniwersytetu Wrocławskiego.

Frank Th. (2004). What's the Matter with Kansas? How Conservatives Won the Heart of America. New York: Metropolitan Books.

Galan K., Piórecka K. (2018). “Analiza zawartości profilu Donalda Trumpa na Twitterze”. In: T. Gackowski, K. Brylska, M. Patera et al. (eds.), Ćwierkajacy Donald Trump (pp. 13-81). Toruń: Wydawnictwo Adam Marszałek.

Gallagher Th. (2019). “The Outsider on the Inside: Donald Trump's Twitter Activity and the Rhetoric of Separation from Washington Culture". Atlantic Journal of Communication, Vol. 27(3), pp. 183-199. DOI: https://doi.org/10.1080/15456870.2019.1610763.

Golbeck J., Grimes J., Rogers A. (2009). Twitter Use by the U.S. Congress. Retrieved from: http:// www.cs.umd.edu/hcil/trs/2009-32/2009-32.pdf (access: 1.01.2020).

Gounari P. (2018). “Authoritarianism, Discourse and Social Media: Trump as the "American Agitator"”. In: J. Morelock (ed.), Critical Theory and Authoritarian Populism (pp. 207227). London: University of Westminster Press.

Greene C.P. (2006). Beyond the Binaries to Self-Fashioning: Identity as the Rhetoric of Social Style. Retrieved from: http://citeseerx.ist.psu.edu/viewdoc/download?doi=10.1.1.428.4400\&rep=rep1\&type=pdf (access: 1.01.2020).

Hallin D.C., Mancini P. (2004). Comparing Media Systems: Three Models of Media and Politics. Cambridge: Cambridge University Press.

Harris A. (2016). Trump on Twitter: A History of the Man and his Medium. Retrieved from: http://www.bbc.com/news/world-us-canada-38245530 (access: 1.01.2020).

Jeziński M. (2009). “Funkcje blogów politycznych”. In: M. Jeziński (ed.), Nowe media i polityka (pp. 181-190). Toruń: Wydawnictwo Adam Marszałek.

Kajtoch W. (2007). "Retoryka dziennikarska”. In: E. Chudziński (ed.), Słownik wiedzy o mediach (pp. 405-419). Bielsko-Biała: Wydawnictwo Szkolne PWN.

Korolko M. (1998). Sztuka retoryki. Przewodnik encyklopedyczny. Warszawa: Wiedza Powszechna.

Kuś R. (2016). “„Odwaga nadziei”. Analiza retoryczna przemówienia Baracka Obamy z 27 lipca 2004 roku”. In: R. Kuś, P. Napierała (eds.), Oblicza Ameryki. Szkice o społeczeństwie, kulturze i polityce Stanów Zjednoczonych (pp. 87-105). Kraków: Księgarnia Akademicka.

Lisowska-Magdziarz M. (2004). Analiza zawartości mediów. Przewodnik dla studentów. Wersja 1.1. Kraków: Wydawnictwo Nieruchomości i Finanse. 
Maguś W. (2018). “Donald Trump kontra media”. Res Rhetorica, Vol. 5(2), pp. 14-28. DOI: https://doi.org/10.29107/rr2018.2.6.

McAdams, D.P. (2017). “The Appeal of the Primal Leader: Human Evolution and Donald J. Trump”. Evolutionary Studies in Imaginative Culture, Vol. 1(2), pp. 1-13. DOI: https://doi. org/10.26613/esic.1.2.45.

McLuhan, M. (2013). Understanding Media: The Extensions of Man. Berkeley: Gingko Press.

Moseley, M. (2018). "Donald Trump and the American Literary Tradition". New Horizons in English Studies, No. 3, pp. 57-70. DOI: https://doi.org/10.17951/nh.2018.3.57.

Olszański L. (2006). Dziennikarstwo internetowe. Warszawa: Wydawnictwa Akademickie i Profesjonalne.

Ott B.L. (2017). “The Age of Twitter: Donald J. Trump and the Politics of Debasement”. Critical Studies in Media Communication, Vol 34(1), pp. 59-68. DOI: https://doi.org/10.1080/ 15295036.2016.1266686.

Parmelee J.H. (2013). “The Agenda-Building Function of Political Tweets”. New Media and Society, 22 ${ }^{\text {nd }}$ May, pp. 1-17. DOI: https://doi.org/10.1177/1461444813487955.

Postman N., Powers S. (2008). How to Watch TV News. New York: Penguin Books.

Robinson D. (2016). Text Analysis of Trump's Tweets Confirms He Writes Only the (Angrier) Android Half. Retrieved from: http://varianceexplained.org/r/trump-tweets/ (access: 1.01.2020).

Sánchez D.M. (2018). "Concientization among People in Support and Opposition of President Trump". Journal of Educational Technology \& Society, Vol. 21(1), pp. 237-247.

Schertzer R., Woods E.T. (2020). “\#Nationalism: the Ethno-Nationalist Populism of Donald Trump's Twitter Communication”. Ethnic and Racial Studies. DOI: https://doi.org/10.108 $0 / 01419870.2020 .1713390$.

Selby J. (2014). Donald Trump retweets picture of serial killers Fred and Rosemary West thinking they are the parents of fan 'inspired' by him. Retrieved from: https://www.independent. co.uk/news/people/donald-trump-retweets-picture-serial-killers-fred-and-rosemarywest-thinking-they-are-parents-fan-inspired-him-9762610.html (access: 1.01.2020).

Silver N. (2015). The Signal and the Noise: Why So Many Predictions Fail - but Some Don't. New York: Penguin Books.

Theye K., Melling S. (2018). “Total Losers and Bad Hombres: The Political Incorrectness and Perceived Authenticity of Donald J. Trump”. Southern Communication Journal, Vol. 83(5), pp. 322-337. DOI: https://doi.org/10.1080/1041794X.2018.1511747.

Wimmer R.D., Dominick J.R. (2008). Mass media. Metody badań. Kraków: Wydawnictwo Uniwersytetu Jagiellońskiego.

Wolff M. (2018). Ogień i furia. Biały Dom Trumpa. Warszawa: Prószyński i S-ka. 